\title{
Purification and characterization of recombinant Streptokinase expressed in E.coli from Streptococcus equisimilis with $\mathbf{N}$-terminal methionine
}

\author{
Vadla Pavan kumar ${ }^{1 a}$, Murali Tummuruª ${ }^{2 b}$, Dinesh Kumar ${ }^{3 c}$ \\ 1Department of Biotechnology, Jawaharlal Nehru Technology University, Hyderabad, India \\ ${ }^{2}$ Research and Development, Virchow Biotech Pvt Ltd Hyderabad, India \\ ${ }^{3}$ Research and Development, Swim Biopharma, Chennai, India
}

aEmail address: pavan6981@gmail.com

bEmail address: mtummuru@yahoo.com

cEmail address: dinesh_trk@yahoo.co.in

\section{HIGHLIGHTS}

- Purification of recombinant streptokinase produced from S.equisimilis in E.coli with $\mathrm{N}$ - terminal methionine.

- Purification by three Chromatography steps: CM sepharose, DEAE sepharose, and Gel filtration.

- Ultrafiltration and diafiltration of the purified streptokinase.

- Streptokinase has two isomers in which one of the isomers is expressed with methionine that shows nil biological activity. Methionine is affecting the biological activity of Streptokinase.

\section{ARTICLE INFO \\ Article history}

Received date: January $30^{\text {th }}, 2019$

Revised date: March 25

Accepted date: May, $03^{\text {rd }}, 2019$

\section{Keywords:}

Characterization

Diafiltration

Electrophoresis

Ultrafiltration

\begin{abstract}
Purification of streptokinase produced from S.equisimilis in E.coli with Nterminal methionine was carried out in 3 Chromatography purification steps, 1) CM-Sepharose-FF at $\mathrm{pH} 4.2$ followed by concentration and dialysis overnight with Tris- $\mathrm{HCl} \mathrm{pH}$ 8.0. Partially purified dialyzed enzyme sample was loaded on to 2) DEAE-Sepharose-FF column. The Purified fractions of DEAE column were pooled and applied on to Sephadex G-100 column. SDS-PAGE and RP-HPLC confirmed enzyme purity.Its biological activity is determined by specific streptokinase assay and characterized the enzyme by Peptide mapping, MALDI-TOF, Isoelectric-focusing, and RPHPLC. The isoelectric point ( $\mathrm{pl}$ ) of streptokinase is around 4.98. The results of characterization show that it contains two forms (Isomers) of streptokinase expressed in E. coli, which was analyzed by RP-HPLC and chromogenic assay. The variation is formed by isomer-1 in which $85 \%$ of Streptokinase expressed without methionine $(85000 \mathrm{IU} / \mathrm{mg})$ and Isomer-2 in which $15 \%$ of streptokinase expressed with methionine (nil activity) in E. coli. This phenomenon shows that the presence and absence of methionine in isomers of streptokinase varying the catalytic activity of the enzyme.
\end{abstract}

This Journal is an open-access article under the CC-BY-SA license.

\author{
${ }^{*}$ Corresponding Author: \\ Vadla Pavan Kumar \\ JNT University, Kukatpally, Hyderabad, India \\ Email address: pavan6981@gmail.com \\ Tel.: +919866108519
}




\section{INTRODUCTION}

In cardiovascular disease management, thrombolytic therapy plays an important role. A thrombus or a blood clot is a solid mass made up of the blood constituents from within the vascular system. These thrombi can break free into pieces and carry to a different location via the blood stream, which leads to the condition known as an embolism. Further, oxygen supply to the surrounding tissue is obstructed by these blockages causing degradation and death. Based upon the location of such thrombi and emboli, they may manifest themselves in the form of different thromboembolic disorders like stroke, pulmonary embolism, deep vein thrombosis, arterial thrombosis, acute myocardial infarction (AMI) and retinal artery occlusion. In 2012 around 17.5 million deaths occurred at an estimated rate of approximately 23.6 million by 2030 , such cardiovascular diseases are progressively becoming the leading cause of morbidity and mortality worldwide. The low and middle-income countries are the most affected due to their socio-economic conditions and inaccessibility to efficient healthcare services. Alterations in the vascular wall, reduction in bloodstream velocity, and an increased tendency of blood coagulation are the three significant variables leading to thrombosis. The Major cause of cardiovascular complications are alcohol abuse, obesity, physical inactivity, unhealthy diet, lifestyle, tobacco use, hypertension, raised blood lipids, diabetes, air pollution, high salt intake combined with age-related risks. $^{1}$

Streptococcus equisimilis GCS strain H46A (ATCC 12449) was the first streptococci to be introduced as a high-yield SK secreting bacteria for production purpose by Christensen et al. in 1945. Further, another Streptococcus. Equisimilis group C (ATCC 9542) was introduced by Estrada et al. as a Streptokinase production strain in 1992. These two strains were used as a principal source of SK gene for heterologous expression of the recombinant SK (rSK) in hosts like E. coli and yeast for SK production. ${ }^{2}$

Plasminogen activators cause thrombolysis via activation of plasminogen into active serine protease plasmin that can degrade the fibrin blood clot. The plasminogen activators mediate fibrin lysis via a direct or an indirect mechanism. The direct plasminogen activators are serine proteases that mediate a direct action on plasminogen to catalyze its activation, e.g., u-PA, pro-urokinase (pro-uPA), t-PA, reteplase ( $r-P A)$, tenecteplase (TNK-tPA), etc. The indirect plasminogen activators (SK, SAK), on the other hand, do not have any enzymatic activity of their own but form a 1:1 stoichiometric complex with plasmin or plasminogen. This activator complex then activates the plasminogen molecules present in the circulation. ${ }^{3}$

Plasminogen activators of human origin (t-PA and $u-P A$ ) are still in use for thrombolytic therapy, but their high cost and side effects have led researchers to look for alternate sources of fibrinolytic enzymes. Due to their low cost of production and fewer side effects, microbial fibrinolytic enzymes have gained proper attention. The enzyme is a single polypeptide that exerts its fibrinolytic action indirectly by activating the circulatory plasminogen. Streptokinase has a molar mass of around $47 \mathrm{kDa}$ which is made up of 414 amino acid residues and exhibits its maximum activity at pH 7.5 without cystine, cysteine, phosphorous, conjugated carbohydrates and lipids. ${ }^{4,5}$

Streptokinase has internal sequence homology between the $\mathrm{NH} 2$-terminal 173 residues and a $\mathrm{COOH}$-terminal 162-residue region between residues 254 and 415 . These two regions have moderate homology in predicted secondary structures. The 80 residues of $\mathrm{COOH}$-terminal region are deleted from the second half of the duplicated structures. The three-dimensional structure of streptokinase likely contains two independently folded domains, each homologous to serine proteases form these observations. ${ }^{6}$

Many thrombolytic agents have been identified and characterized from different sources, including fermented food products like Japanese natto, ${ }^{7}$ Korean chunkook- 
jang $^{8}$, and Chinese douchi ${ }^{9}$, food grade microorganisms ${ }^{10,11}$, insects ${ }^{12}$, polychaetes ${ }^{13}$, earthworms ${ }^{9,14}$, and snake venom. ${ }^{15}$ Microorganisms have various thrombolytic agents and gained particular medical interest because of their broad biochemical diversity, the feasibility of mass culture, and ease of genetic manipulation. Hence, a variety of microorganisms has been used for isolation of fibrinolytic enzymes, which include bacteria, fungi, and algae. Various methods of purifying streptokinase have been described which are based on quantitative differences in solubility, electrical charge, molecular size, and shape or non-specific physical interactions with surfaces. ${ }^{16}$ Recently have produced untagged recombinant streptokinase and purified it with three chromatography purification steps.

\section{MATERIALS AND METHOD}

The materials used in the experiment include harvest culture of Streptococcus equisimilis group C, strain H46A (ATCC 12449, USA), High-speed Refrigerated centrifuge from Hitachi CR212GIII, Japan. A French press is from of Panda plus-Niro saovi, Italy; Refrigerated circulator is from Julabo, Germany. FPLC system (Akta prime plus) is from GE-Healthcare, $0.2 \mu \mathrm{m}$ disc filters(PALL Life sciences), CM-sepharose-FF (GE-Healthcare), DEAE Sepharose-FF, Sephadex G100 (GE-Healthcare, USA) (GEHealthcare, USA), Electrophoresis unit (AE-6500-Atto corporation, Japan) SDS PAGEHPLC (Agilent Technologies, USA), Chromogenic substrate S-2251 (Chromogenix laboratories, Italy), Buffer salts, acids and bases (Merck, Germany).

\section{RESULTS AND DISCUSSION}

3.1. Purification of streptokinase

Streptokinase was purified by 3 step chromatography. Following are the steps involved for purification. The cell harvest obtained from 2-liter fermentation batch was centrifuged at $4000 \mathrm{rpm}$, and the pellet was stored at $-80^{\circ} \mathrm{C}$ for cell lysis. Cell lysis was performed on French press (Niro saovi-Italy) at a pressure of $16 \mathrm{Kpsi}$ (2 cycles.), lysis was carried out at $15^{\circ} \mathrm{C}$ using the refrigerated circulator (Julabo, Germany). The buffer used for cell lysis was $20 \mathrm{mM}$ sodium acetate $\mathrm{pH}$ 4.2. After cell lysis, the lysate was clarified at $20000 \mathrm{~g}$ for $30 \mathrm{~min}$ at $4^{\circ} \mathrm{C}$ and separated the supernatant from the cell debris. The separated supernatant was filtered with $0.2 \mu \mathrm{m}$ disc filters and used for first purification step on CM-sepharose column (XK-26/20-40 ml). Loaded the filtered supernatant on to the column at $\mathrm{pH} 4.2$ with a flow rate of $2.5 \mathrm{ml} / \mathrm{min}$. Washed the column with wash buffer to remove other unbound proteins. The bound enzyme was eluted with a linear gradient of $0-500 \mathrm{mM} \mathrm{NaCl}$ in $20 \mathrm{mM}$ sodium acetate buffer. Partially purified streptokinase was eluted at $75 \mathrm{mM} \mathrm{NaCl}$ step which was further purified by anion exchange chromatography using DEAE Sepharose-FF at $\mathrm{pH} 8.0$ with $20 \mathrm{mM}$ Tris $-\mathrm{HCl}$. The partially purified pooled fractions streptokinase were dialyzed with $20 \mathrm{mM}$ Tris- $\mathrm{HCl}$ and loaded on to DEAE column and eluted with a linear gradient of $0-500 \mathrm{mM} \mathrm{NaCl}$ where the purified enzyme eluted at $150 \mathrm{mM} \mathrm{NaCl}$ step. Purified fraction of DEAE was passed on to Sephadex G100 column(length:30 cm, Diameter: $7.8 \mathrm{~mm}$ ) to get a purity of $>99 \%$.Buffer used for this column is $20 \mathrm{mM}$ sodium phosphate, $150 \mathrm{mM} \mathrm{NaCl} \mathrm{pH} \mathrm{8.0.} \mathrm{All} \mathrm{purifications} \mathrm{were} \mathrm{carried} \mathrm{out} \mathrm{on} \mathrm{FPLC} \mathrm{system}$ (Akta prime plus, GE-Healthcare).

\subsection{Quantification and electrophoresis of protein}

The molecular mass and purity of the streptokinase were determined by $12 \%$ SDS polyacrylamide gel electrophoresis with Atto equipment (Japan). Proteins were visualized by staining with Coomassie Brilliant Blue R- 250 or with $0.1 \%(w / v)$ of silver nitrate.

Protein determination involves the binding of Coomassie Brilliant Blue G-250 to protein. The dye binding to protein causes a shift in the absorption maximum from 465 
to $595 \mathrm{~nm}$, and the increase in absorption at $595 \mathrm{~nm}$ is monitored. This assay is very reproducible and rapid with the dye binding process virtually complete in approximately 2 min with good color stability for $1 \mathrm{hr}$. Protein quantification was done by the Bradford dye binding assay with the bovine serum albumin as standard. ${ }^{17,18}$

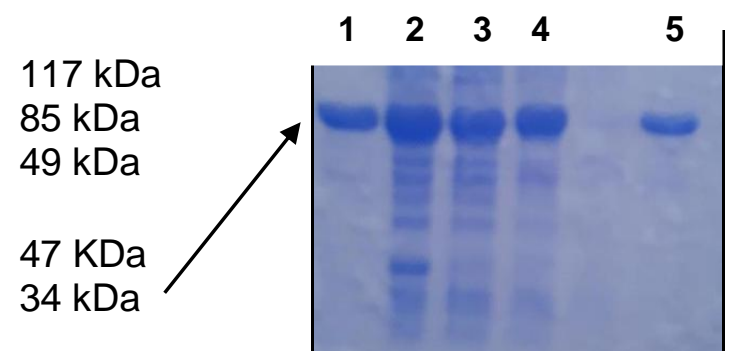

Figure 1. Evaluation of streptokinase purification by SDS-PAGE (Gel-1).

1) Standard; 2) Column 1-CM sepharose-FF; 3) Column 2-DEAE sepharose-FF;

4) Column 3- Sephadex G100; 5) Purified SK

$\begin{array}{llllll}1 & 2 & 3 & 4 & 5 & 6\end{array}$

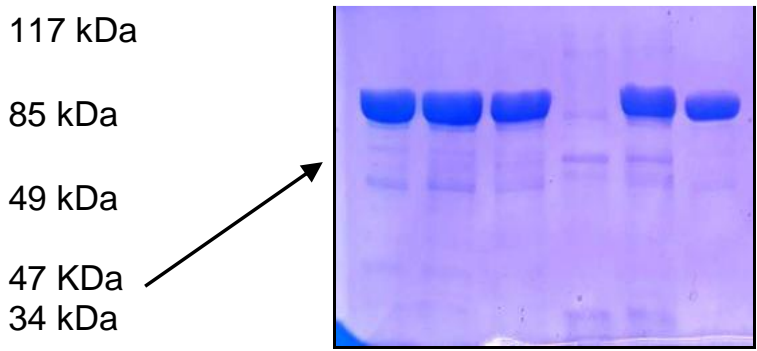

Figure 2. Evaluation of streptokinase purification by SDS-PAGE (Gel-2).

1)Column 3 sephadex G100; 2) Column 2 DEAE sepharose-FF; 3) Column 1-CM sepharoseFF; 4) Blank; 5) Purified SK (In-house); 6) Polished purified SK.

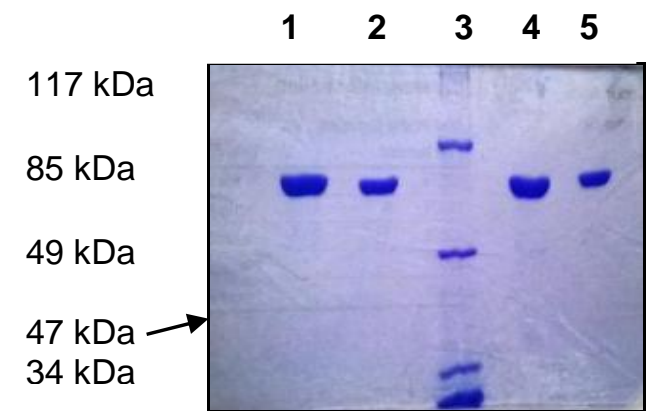

Figure 3. Evaluation of standard and purified streptokinase by SD-PAGE.

1)Standard-10 $\mu \mathrm{g}$; 2) Standard-5 $\mu \mathrm{g}$; 3) Molecular weight marker; 4) Purified Streptokinase-10 $\mu \mathrm{g}$; 5) Purified Streptokinase-5 $\mu \mathrm{g}$

Table 1. Purification table of Streptokinase

\begin{tabular}{ccccccc}
\hline Sample & $\begin{array}{c}\text { Total } \\
\text { protein } \\
(\mathrm{mg})\end{array}$ & $\begin{array}{c}\text { Streptokinase } \\
(\mathrm{IU})\end{array}$ & $\begin{array}{c}\text { Streptokinase } \\
(\mathrm{IU} / \mathrm{mg})\end{array}$ & $\begin{array}{c}\text { Fold } \\
\text { purification }\end{array}$ & $\begin{array}{c}\text { Protein } \\
\text { Yield } \\
(\%)\end{array}$ & $\begin{array}{c}\text { Activity } \\
\text { Recovery } \\
(\%)\end{array}$ \\
\hline $\begin{array}{c}\text { Crude extract } \\
400\end{array}$ & 6000000 & 15000 & 1 & 100 & 100 \\
$\begin{array}{c}\text { Purified, CM- } \\
\text { Sepharose FF }\end{array}$ & 252 & 5418000 & 21500 & 1.4 & 63 & 90 \\
$\begin{array}{c}\text { Purified, } \\
\text { DEAE- }\end{array}$ & 105 & 4788000 & 45600 & 3.0 & 26 & 88 \\
$\begin{array}{c}\text { Sepharose FF } \\
\begin{array}{c}\text { Purified, } \\
\text { Sephadex-100 }\end{array}\end{array}$ & 54 & 4584600 & 84900 & 5.7 & 14 & 96 \\
\hline
\end{tabular}


The recombinant streptokinase mass analysis was done by using a Bruker Daltonics flex Analysis MALDI-TOF (matrix-assisted laser desorption ionization - a time of flight) mass spectrometer. Sinapinic acid matrix solution $(10 \mathrm{mg})$ per $\mathrm{ml}$ in acetonitrile-water (1:1) was prepared, mixed with an equal amount ( $\mathrm{vol} / \mathrm{vol})$ of dialyzed protein solution, and spotted on a sample plate. Then the mass spectra were recorded. ${ }^{19}$

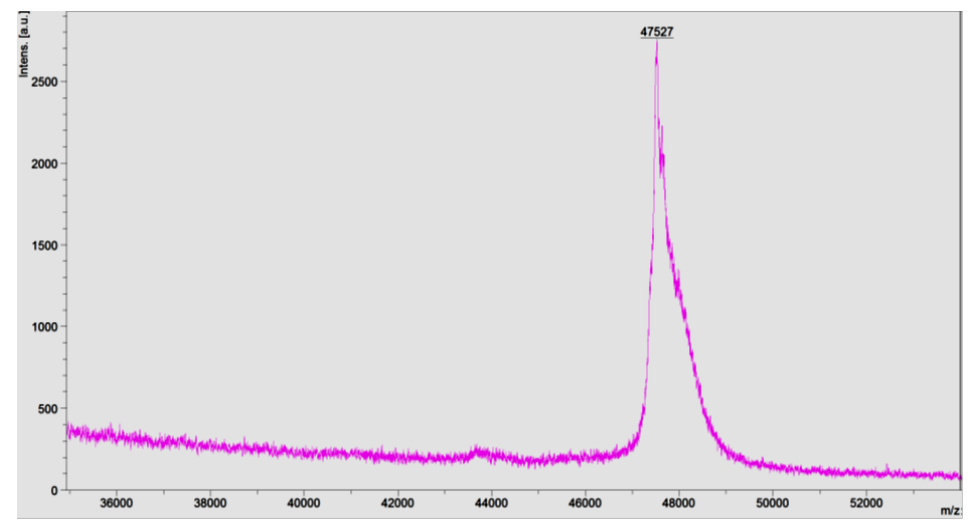

Figure 4. MALDI-TOF mass spectral analysis of recombinant streptokinase. MALDI-TOF

Powder samplel0_E20 11\1Lin

BrukerDaltonicsflexAnalysisprinted: 11/16/2017 7:13:31 PM

Molecular weight for Streptokinase

\subsection{Peptide mapping}

Peptide mapping is a relative procedure because the information obtained, compared to a reference standard or reference material similarly treated, confirms the primary structure of the protein, is capable of detecting whether alterations in structure have occurred, and demonstrates process consistency and genetic stability. ${ }^{20}$

Reagents and Chemicals using Acetronitrile and Orthophosphoric acid obtained from Sigma and Fisher scientific respectively, the water used for a reaction was Milli-Q Water (Millipore Corp.) with 18 mega ohms or less resistance. TPCK (L-I-tosylamido-2phenylethyl chloromethyl ketone)-treated trypsin was ordered from Worthington and $\mathrm{N}$ ethyl morpholine and TLCK (N,-p-tosyl-L-lysine chloromethyl ketone)-treated chymotrypsin from the make Sigma. A Waters Associates liquid chromatograph equipped with gradient elution capability, a U6K sample injector, fixed dual wavelength detector, and a variable wavelength detector was employed. Performed all separations on reversed phase column (IO pm, $4 \mathrm{~mm} \times 30 \mathrm{~cm}$ ), from water associates. ${ }^{15}$

Elution of peptides was carried out by the use of a linear gradient, from $0.1 \%$ orthophosphoric acid (Solvent A) to acetonitrile (Solvent B) at a constant flow rate of 2 $\mathrm{ml} / \mathrm{min}$ with 500 to 1000 p.s.i varying column pressure. Filtered the Phosphoric acid (0.1\%, pH 2.2) through a 0.5 pm Millipore filter (Millipore Corp., Bedford, MA) and degassed under vacuum for $30 \mathrm{~min}$, with stirring. Acetonitrile was used directly. Solvents were stirred continuously during runs to eliminate the formation of temperature gradients and performed all runs at room temperature.

The column precision can be maintained by pumping acetonitrile at $0.1 \mathrm{ml} / \mathrm{min}$ through the column overnight. The column was equilibrated with Solvent $A$ for ten min. ${ }^{15}$ Buffers such as $0.2 \mathrm{~N} \mathrm{~N}$-ethyl morpholine acetate $(\mathrm{pH} 8.1)$ at $37^{\circ} \mathrm{C}$ were used for enzymatic digestion with an enzyme to protein ratio of 1 to $100(\mathrm{w} / \mathrm{w})$. Acetic acid was added to stop the digestion. The test samples were directly injected into the HPLC without any manipulation. The compositions of proteins and peptides were determined 
on a Beckman model $119 \mathrm{Cl}$ analyzer equipped for single column methodology. The samples were lyophilized ( 1 to $5 \mathrm{nmol}$ ) in hydrolysis ampoules and vacuum hydrolyzed for $24 \mathrm{~h}$ at 110 ' $\mathrm{C}$ in $1.0 \mathrm{ml}$ of constant-boiling $\mathrm{HCl}^{15}$

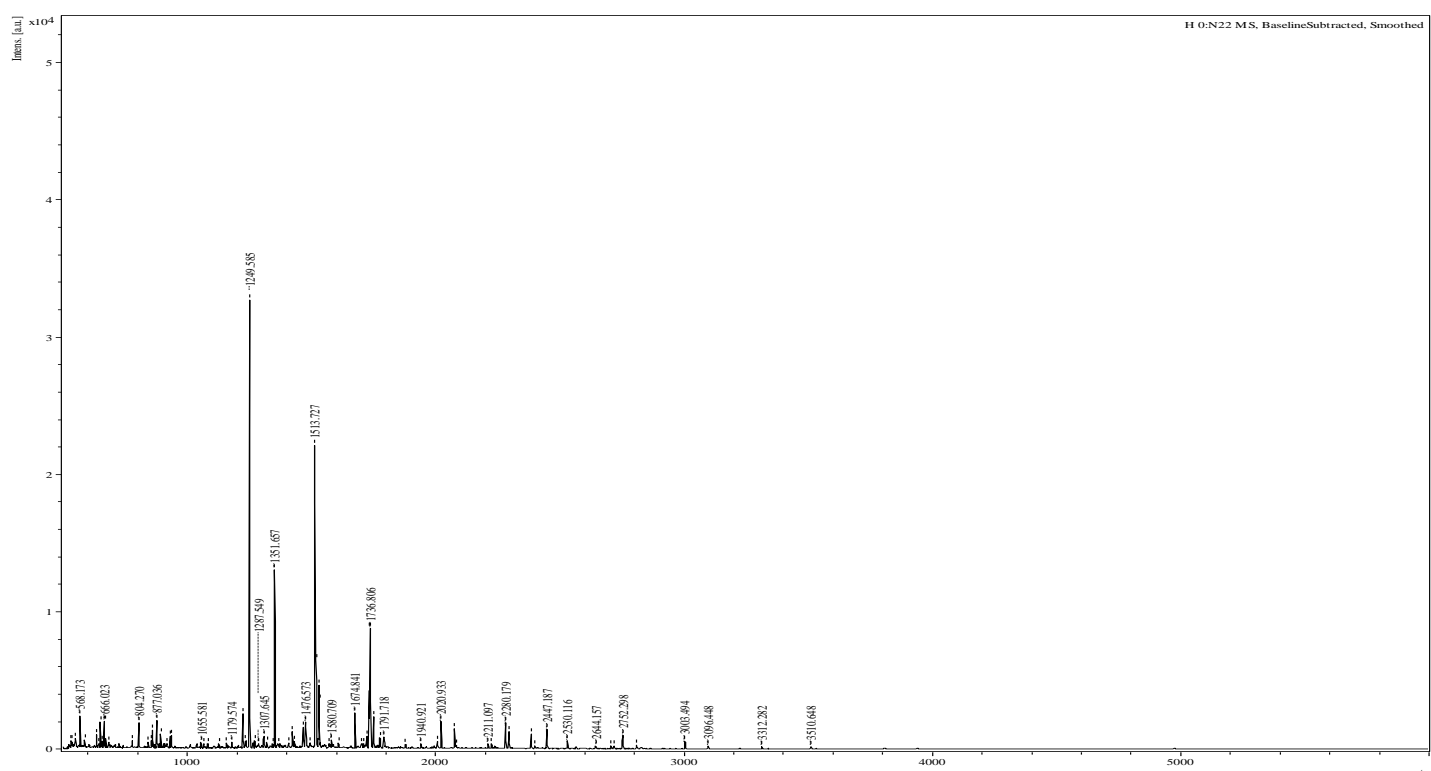

Figure 5. Peptide mapping of recombinant streptokinase.

\subsection{Isoelectric focusing}

Immobilized $\mathrm{pH}$ gradient (IPG) strip commercially available is used. The Acrylamide gel of IPG strip contains wide pores which prevent a sieving effect based on protein mass, with a $\mathrm{pH}$ gradient. Different gradients are available, with broader gradients, at $\mathrm{pH}$ 3-10 for whole proteome analysis, and narrower ranges, at $\mathrm{pH} 5-8$ used for more specialist applications. ${ }^{21}$ Equipments and Reagents using Gel casting apparatus for a horizontal electrophoresis cell, Fluorescent lamp, $30 \%$ T, $3 \%$ C Acrylamide stock solution, $50 \%$ glycerol, $0.1 \%$ riboflavin- 5 '- phosphate(FMN), carrier ampholytes with a pH range spanning the $\mathrm{p} / \mathrm{s}$ of the protein of interest, $10 \%$ APS and TEMED. ${ }^{22}$ Equipments and reagents using Flat-bed electrophoresis cell-The GE multiphor,Power supply capable of delivering 2- $3000 \mathrm{~V}$ and $6 \mathrm{~W}$ at high voltage, Refrigerated water circulator, Electrode strips, sample application strips, $1 \mathrm{~N} \mathrm{NaOH}$ catholyte, $1 \mathrm{~N} \mathrm{H} 3 \mathrm{PO} 4$ anolyte. ${ }^{22}$

Procedure using set up the IEF cell as recommended by the manufacturer. Connected water circulator and prepared the cooling platform and electrode strips. Placed the sample application strips on a glass plate and pipette $5 \mu$ l of a protein sample to each strip. Place the application strips $1 \mathrm{~cm}$ from the anode end of the gel. Positioned the gel in the IEF cell and make electrode contact as specified for the particular cell. Close the electrophoresis cell and connect the leads to the power supply. The red lead is the anode, and the black lead is the cathode. Set the running conditions as recommended by the manufacturer of the electrophoresis cell. ${ }^{22}$ 


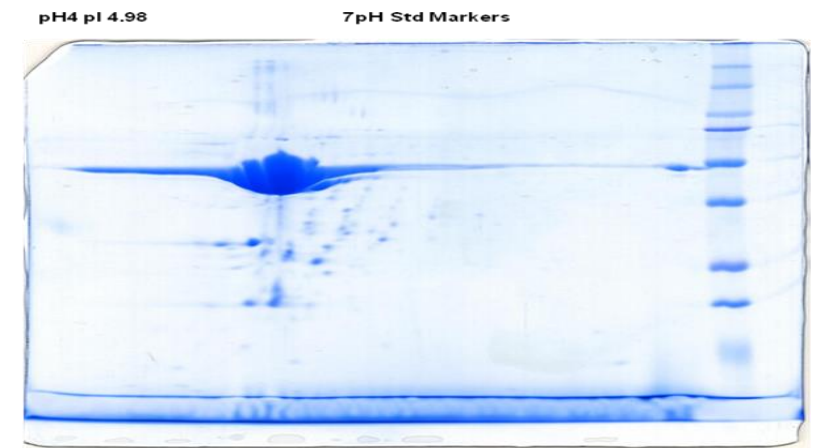

Figure 6. Isoelectric focusing of recombinant Streptokinase: $250 \mathrm{ug}, 13 \mathrm{~cm}$, pl 4-7, CBB staining.

\subsection{Reverse Phase - HPLC}

The purified streptokinase sample is obtained $20 \mathrm{mg} / \mathrm{ml}$. Further, the sample was diluted in $1 \mathrm{mg} / \mathrm{ml}$ with $20 \mathrm{mM}$ phosphate buffer $\mathrm{pH} 7.5$. $100 \mu \mathrm{l}$ of sample is injected to Agilent HPLC system with C18 reverse phase column size $250 \mathrm{mmx} 0.46$. The mobile phase solvent $A$ is water with $0.001 \%$ TFA (Trifluro acetic acid), and mobile phase $B$ is $40: 60 \%$ of methanol and acetonitrile. The total run time process on HPLC is 70 minutes with gradient mode using the absorbance at $280 \mathrm{~nm}$. The same procedure was followed for standard streptokinase.

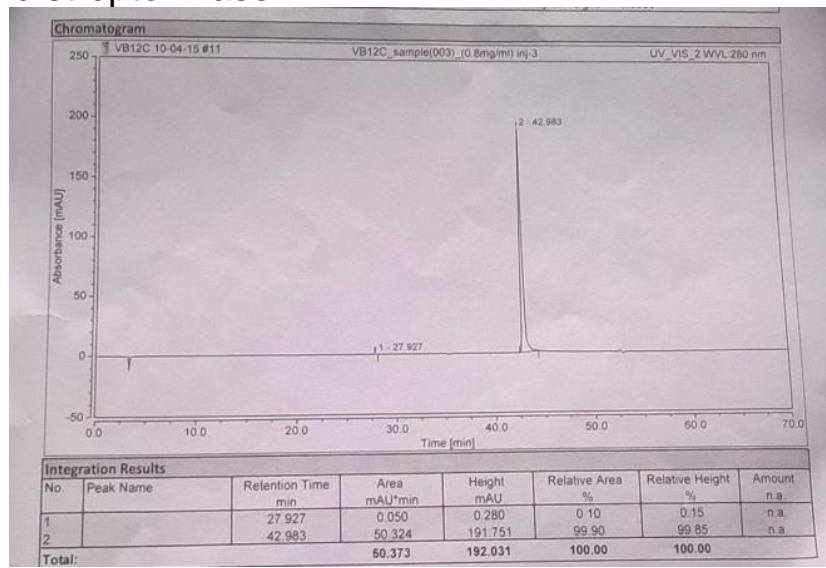

Figure 7. Reverse phase Chromatogram of Purified Streptokinase.

The retention time of purified streptokinase is 42.983 and the observed purified streptokinase purity is 99.9

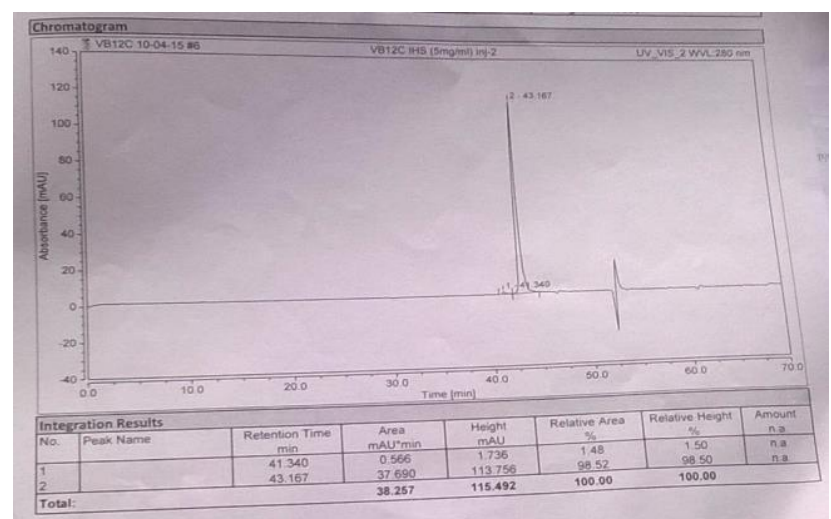

Figure 8. Reverse phase Chromatogram of standard purified Streptokinase.

The retention time of standard streptokinase is 42.167 , and the observed standard streptokinase purity is 98.52 . 


\subsection{Streptokinase chromogenic substrate assay (scsa)}

Twenty-five microliter volumes of the STK and the sample solutions with concentrations between 2.5 and $40 \mathrm{IU} / \mathrm{mL}$ were added to the 96 -well plate, respectively in triplicate, and equilibrated at $37^{\circ} \mathrm{C}$ in a water bath for $1 \mathrm{~min}$. Incubated the plate for 2 min after adding $100 \mu \mathrm{L}$ of the chromogenic substrate (diluted 1:1 in water) into each well, Then added $50 \mu \mathrm{L}$ of the $1 \mathrm{mg} / \mathrm{mL}$ plasminogen. Stop the reaction by adding 90 $\mu \mathrm{L}$ of $20 \%$ acetic acid after $10 \mathrm{~min}$ and measured the absorbance at $405 \mathrm{~nm}$ in the microplate reader. Calculated the biological potencies against STK by the parallel line statistical method using the CombiStats software. ${ }^{17,23}$

\subsection{Clot lysis assay}

The fibrin clot lysis method is based on the clotting of fibrinogen in the presence of plasminogen and streptokinase.

Two solutions prepared fibrin plate:

Solution 1: Dissolved $200 \mathrm{mg}$ of agarose (Merck, USA) in $20 \mathrm{~mL}$ of phosphate buffer solution and $\mathrm{pH}$ adjusted to 7.2 . Maintain the solution at $56^{\circ} \mathrm{C}$.

Solution 2: Dissolved $50 \mathrm{mg}$ of human fibrinogen (Fibrinogen, Fraction 1, Type 1 from Human Plasma, Sigma-Aldrich, USA) in $10 \mathrm{~mL}$ phosphate buffer solution $(\mathrm{pH}=7.2) .{ }^{24}$

To Solution $12000 \mu \mathrm{L}$ of $1 \mathrm{mg} / \mathrm{mL}$ human plasminogen (Human plasminogen, Hyphen Biomed, France) was added and to Solution 2, $500 \mu \mathrm{L}$ of thrombin (10 NIH unit/vial, from human plasma, Sigma-Aldrich, USA) was added. By mixing solutions (1) and (2) in a Petri dish, clot formation was initiated for 30 min and maintained at $4^{\circ} \mathrm{C}$. Dilutions were prepared in the range of $100-1000 \mathrm{IU} / \mathrm{mL}$, with Milli-Q water from the international standard and loaded, as duplicate, onto fibrin plate and incubated for eighth. The dose-response curve for streptokinase was obtained by measuring the zones of lysis produced on the fibrin plates. By reconstituting each vial with $1 \mathrm{~mL}$ of Milli-Q water, the test samples were prepared. Streptokinase activity of the samples using the dose-response curve was determined from zones of lysis that was produced by allocated dilutions of each sample loaded on fibrin plates. ${ }^{23}$

The results of the Streptokinase (SK) purification by CM-Sepharose FF, DEAE sepharose, and Sephadex G100 are shown in Table 1. In the first column purification by CM-sepharose the enzyme was purified 1.4 fold with a yield of $63 \%$ and activity recovery of $90 \%$. In this step, 252 milligrams $(\mathrm{mg})$ pure streptokinase was produced; the purified product had a specific activity of $21500 \mathrm{IU} / \mathrm{mg}$. In the second column purification by DEAE, the enzyme was purified 3.0 fold with a yield of $26 \%$ and activity recovery of $88 \%$. In this step, 105 milligrams $(\mathrm{mg})$ pure streptokinase was produced; the purified product had a specific activity of $45600 \mathrm{IU} / \mathrm{mg}$. In the third column purification by Sephadex G100, the enzyme was purified 5.7 fold with a yield of $14 \%$ and activity recovery of $96 \%$. In this step, 54 milligrams $(\mathrm{mg})$ pure streptokinase was produced; the purified product had a specific activity of $84900 \mathrm{IU} / \mathrm{mg}$. In an SDSPAGE analysis, the eluted product of three columns showed a single band of approximately $47 \mathrm{kDa}$ (Figure 1 and Figure 2). In RPHPLC analysis purified Streptokinase showed a purity of $\sim 99.9 \%$ with a retention time of $\sim 42.98$ min where the standard streptokinase showed a purity of $\sim 98.5 \%$ with a retention time of $\sim 42.16 \mathrm{~min}$. The results of Mass spectral analysis of recombinant streptokinase by MALDI-TOF showed a molecular weight of $\sim 47.5 \mathrm{KD}$. Based on the results of Isoelectric focusing the pl of recombinant streptokinase is $\sim 4.98$. The results of peptide mapping showed that the amino acid sequences of standard and recombinant streptokinase are identical. The results of RPLC showed that streptokinase was expressed in two isoforms (isomers). Isomer-1 has $85 \%$ SK expressed without methionine, and Isomer-2 has $15 \%$ SK expressed with methionine, which showed nil activity. 
To investigate the impact of an amino-terminal methionine on the catalytic activity of streptokinase, the mature native streptokinase sequence (rSK) was cloned. The $\mathrm{N}$ terminal amino acid of native streptokinase started with Isoleucine (I), Alanine (A) and Glycine $(G)$ and followed by Proline $(P)$, etc. The first amino acid of Isoleucine is playing an essential role in the catalytic activity of streptokinase is binding towards inactive plasminogen to activate plasminogen. The specific activity of native streptokinase is $100000 \mathrm{IU} / \mathrm{mg}$ with the initial $\mathrm{N}$ - terminal isoleucine amino acid.

Despite the recombinant streptokinase begins with a proteinogenic aminoterminal methionine (rSK-Met) for expression and is not susceptible to processing during expression The presence of the amino-terminal methionine in rSKMet was confirmed by protein sequencing. Comparison of the specific activity of recombinant streptokinase shows only $85000 \mathrm{lU} / \mathrm{mg}$ than $100000 \mathrm{IU} / \mathrm{mg}$ native streptokinase. The reason behind this objective is that there are two forms (Isomers) of streptokinase are expressed in E. coli, which was analyzed by RP-HPLC and chromogenic assay. We have found that isomer-1 forms this variation have $85 \%$ of Streptokinase expressed without methionine $(85000 \mathrm{IU} / \mathrm{mg})$ and Isomer-2 has $15 \%$ of streptokinase expressed with methionine (nil activity) in E. coli. This phenomenon is demonstrating that the presence and absence of methionine in isomers are varying the catalytic activity of streptokinase.

\section{CONCLUSION}

SK is one of the promising blood-clot dissolving agents for the treatment of patients suffering from a heart attack. It is crucial to produce this enzyme in large quantities for biochemical characterization and clinical trials. In this work, we found and observed that streptokinase has two isomers where one of the isomers has nil activity because of methionine. Hence methionine in isomers is affecting the activity of streptokinase. The production and purification of efficient and low-cost r-SK are possible only with one of the isomers for pharmaceutical applications. This technology or new finding plays an essential role in the successful production of bioactive r-SK and to scale up the production process using fermentation technology.

\section{ACKNOWLEDGMENT}

This study was supported by Swim Biopharma Pvt Ltd and Virchow Biotech Pvt Ltd. I would like to appreciate and thank Swim Biopharma Pvt Ltd and Virchow Biotech Pvt Ltd for providing required Instruments, chemicals and reagents for carrying out my research work.

\section{REFERENCE}

1. Adivitiya, Khasa Y. The evolution of recombinant thrombolytics: Current status and future directions Bioengineered. 2017;8(4):331-358.

2. Keramati M, Roohvand F, Aslani MM, et al. Screening, Cloning and Expression of Active Streptokinase from an Iranian Isolate of S.equisimilis Group C in E. coli. Iran J Basic Med Sci. 2013;39:405-423.

3. Taylor FB, Botts J. Purification and characterization of streptokinase with studies of streptokinase activation of plasminogen. Biochemistry. 1968;7(1):232-240.

4. Felsia XF, Vijayakumar R, Kalpana S. Production and partial purification of streptokinase from Streptococcus pyogenes. J Biochem Tech. 2011;3(3):281289.

5. Collen D, Stump DC, Gold HK. Thrombolytic therapy. Annu Rev Med. 1988;39:405-423.

6. Jackson KW, Tang J. Complete Amino Acid Sequence Of Streptokinase And Its Homology With Serine Proteases. Biochemistry. 1982;21:6620-6625.

7. Sumi H, Yanagisawa Y, Yatagai C, Saito J. Natto Bacillus as an oral fibrinolytic 
agent: nattokinase activity and the ingestion effect of Bacillus subtilis natto. Food Sci Technol Res. 2004;10:17-20.

8. Kim W, Choi K, Kim Y, Park H, Choi J, Lee Y. Purification and characterization of a fibrinolytic enzyme produced from Bacillus sp. strain CK 11-4 screened from chungkook-jang. Appl Environ Microbiol. 1996;62:2482-2488.

9. Wang CT, Ji BP, Li B, et al. Purification and characterization of a fibrinolytic enzyme of Bacillus subtilis DC33, isolated from Chinese traditional douchi. $J$ Ind Microbiol Biotechnol. 2006;33:750-758.

10. Wang X, Cheng Q, Xu L, Feuerstein G, Shu MY, Smith P. Effects of factor IX or factor XI deficiency on ferric chloride-induced carotid artery occlusion in mice. $J$ Thromb Haemost. 2005;3:695-702.

11. Deepak V, Kalishwaralal K, Ramkumarpandian S, Babu S V, Senthilkumar S, Sangiliyandi G. Optimization of media composition for nattokinase production by Bacillus subtilis using response surface methodology. Bioresour Technol. 2008;99:8170-8178.

12. Ahn MY, Hahn BS, Ryu KS, Kim JW, Kim I, Kim YS. Purification and characterization of a serine protease with fibrinolytic activity from the dung beetles, Catharsius molossus. Thromb Res. 112:339-347.

13. Deng Z, Wang S, Li Q, Ji X, Zhang L, Hong M. Purification and characterization of a novel fibrinolytic enzyme from the polychaete, Neanthes japonica (Iznka). Bioresour Technol. 2010;101:1954-1960.

14. De-Simone S, Correa-Netto C, Antunes O, De-Alencastro R, Silva JF. Biochemical and molecular modeling analysis of the ability of two paminobenzamidine-based sorbents to selectively purify serine proteases (fibrinogenases) from snake venoms. J Chromatogr. 2005;822:1-9.

15. Fullmer CS, Wasserman $\mathrm{RH}$. Analytical Peptide Mapping by High Performance Liquid Chromatography, Application to intestinal calcium-binding proteins. $J$ Biol Chem. 1979;254:7208.

16. Karimi Z, Babashamsi M, Asgarani E, Niakan M, Salimi A. Fermentation, fractionation and purification of streptokinase by chemical reduction method. $J$ Microbiol Iran. 2011;3(1):42-46.

17. R Jafari, Mirshahi M. Production and purification of recombinant streptokinase using pMAL expression vector. Tehran Univ Med J. 2007;65:13-18.

18. Bradford MM. A Rapid And Sensitive Method For The Quantitation Of Microgram Quantities Of Protein Utilizing The Principle Of Protein-Dye Binding. Anal Biochem. 1976;72:248-254.

19. Caballero AR, Lottenberg R, Johnston HK. Cloning, Expression, Sequence Analysis, and Characterization of Streptokinases Secreted by Porcine and Equine Isolates of Streptococcus equisimilis. Infect Immun. 1999;67(12):64786486.

20. Peptide Mapping, First Interim Revision Announcement: Biotechnology. Deriv Artic. 2016;35(1).

21. Jones $P$. Isoelectric focussing for separation of proteins and peptides.

22. Garfin DE. Isoelectric focusing, AES application focus. Garfin _IEF_Webarticle. 9(7):4-7.

23. Xavier B, Camponogara $R L$, Appratto $C D$, et al. Validation of the Chromogenic Bioassay for the Potency Assessment of Streptokinase in Biopharmaceutical Formulations. J Anal Bioanal Tech. 2015;6(6).

24. Mahboubia A, Sadjadyc SK, Abadid MMS, Azadid S, Solaimanian R. Biological Activity Analysis of Native and Recombinant Streptokinase Using Clot Lysis and Chromogenic Substrate Assay. Iran J Pharm Res. 2012;11(4):1087-1093. 